


\title{
AKTUALISASI PENDIDIKAN ISLAM DALAM PENGELOLAAN LINGKUNGAN HIDUP: Studi Relasi Antara Pendidikan Islam dan Budaya Mistis Dalam Pelestarian Lingkungan
}

\section{Dedi Wahyudi Siti Aisah}

Institut Agama Islam Negeri (IAIN) Metro

Jl. Ki. Hajar Dewantara 15 A Kampus Iring Mulyo, Metro Timur Kota Metro 34111

Email: podoluhur91@gmail.com \& Sitiaisahukhty@gmail.com

\begin{tabular}{|c|c|c|}
\hline Diterima: & Revisi: & Disetujui: \\
10 Maret 2018 & 10 April 2018 & 22 Mei 2018 \\
\hline
\end{tabular}

\begin{abstract}
This study aims to describe the relationship between Islamic Education and Mystical Culture in Environmental Conservation. This research is a study of literature by collecting the same source as much as possible. There is much research relevant to this journal article. From the analysis of the various studies, the result of this research is the relationship between Islamic education and mystical culture in the preservation of the environment that is the positive side and the negative side. The positive side is that with the existence of a mystical culture that exists in society makes society not arbitrary to nature, people who embrace and believe in the mystical is more polite, more careful when doing or connect with nature. While the negative side of the community that embraces or believes in the existence of this mystical tend to put forward and glorify the culture compared with Islam that dianutnya.
\end{abstract}

Keyword: Education, Islam, and Mystic

\begin{abstract}
Abstrak
Penelitian ini bertujuan untuk mendeskripsikan Hubungan Antara Pendidikan Islam dan Budaya Mistis Dalam Pelestarian Lingkungan. Penelitian ini merupakan penelitian kajian pustaka dengan mengumpulkan sumber yang sama sebanyak-banyaknya. Ada banyak penelitian relevan dengan artikel jurnal ini. Dari analisis dari berbagai penelitian tersebut, maka hasil dari
\end{abstract}


penelitian ini yaitu adanya relasi antara pendidikan Islam dan budaya mistis dalam pelestarian lingkungan yaitu terdapat sisi positif dan sisi negatif. Sisi positifnya yaitu dengan adanya budaya mistis yang ada pada masyarakat menjadikan masyarakat tidak semena-mena terhadap alam, masyarakat yang menganut dan mempercayai adanya mistis ini lebih sopan, lebih berhati-hati ketika melakukan atau berhubungan dengan alam. Sedang sisi negatifnya yaitu masyarakat yang menganut atau mempercayai adanya mistis ini cenderung lebih mengedepankan dan mengagung-agungkan budayanya dibanding dengan agama Islam yang dianutnya.

Kata Kunci: Pendidikan, Islam, dan Mistis

\section{A. Pendahuluan}

Manusia merupakan makhluk hidup yang senantiasa berinteraksi dengan lingkungan tempat hidupnya. terkadang manusia yang mempengaruhi lingkungan dan terkadang lingkungan yang mempengaruhi manusia. Keberlangsungan hidup manusia tergantung pada kemampuan manusia itu untuk menyesuaikan diri dengan lingungan tempat hidupnya. Ketergantungan manusia ini sudah ditentukan oleh proses seleksi yang terjadi selama jutaan tahun dalam evolusi manusia. Jika terjadi perubahan sifat pada lingkungan hidup di luar batas adaptasi manusia baik perubahan yang terjadi secara alamiah maupun perubahan yang terjadi karena disebabkan oleh aktifitas hidup manusia, maka keberlangsungan hidupnya akan terancam. ${ }^{1}$

Alam merupakan anugerah tebesar yang Allah berikan kepada manusia. Tempat yang bisa dihuni oleh manusia, hewan dan tumbuhan yang memilki berbagai kelebihan dibanding dengan planet lainya, yang tidak bisa dihuni oleh mahluk hidup. Mempunyai kelimpahruahan yang luar biasa seperti kadar oksigen, air, dan lain sebagainya. ${ }^{2}$ Sebab itulah, menurut Muzakki masing-masing elemen

1 Jumarddin La Fua, "Aktualisasi Pendidikan Islam dalam Pengelolaan Lingkungan Hidup menuju Kesalehan Ekologis," Al-Ta'dib 7, no. 1 (2014): 19-36.

2 Haidi Hajar Widagdo, "Relasi Alam dan Agama (Sebuah Upaya Penyelarasan antara Budaya Mistis dengan Pelestarian Lingkungan)," ESENSIA: Jurnal Ilmu-IImu Ushuluddin 13, no. 2 (2012): 263-276. 
memiliki sinergitas dengan kadar dan ukuran yang telah ditentukan oleh Allah SWT sebagai penciptanya. ${ }^{3}$

Kekayaan yang melimpah ini Allah berikan gratis kepada makhluk-Nya untuk menjaga, mengelola, dan merawat alam ini, Allah berikan tugas dan kepercayaan yang penuh kepada manusia agar menjaga dan merawatnya dengan sebaik-baiknya. Memanfaatkan alam dengan tidak menzolimi alam tersebut, merawat dengan sebaikbaiknya untuk menjaga kepercayaan Allah kepada manusia. Tidak merusak alam dengan tangan-tangan jahil.

Seiring dengan berjalannya evolusi manusia, ada beberapa manusia yang mengingkari tugas dan kewajiban sebagai makhluk Allah yang harus menjaga alam ini, mereka berani menghianati kepercayaan Allah yang telah diberikan kepadanya dan bahkan ada sebagian dari mereka dengan paksa memerkosa alam dengan sedemikian rupa, sehingga kekayaan alam seperti air dan udara yang dahulu bersih dan sehat menjadi tercemar dengan zat-zat yang berbahaya yang menyebabkan polusi udara dan air yang ada dibumi menjadi tercemar.

Ekspolitasi besar-besaran terhadap sumber daya alam, seperti penggalian hasil bumi seperti batu bara, penebangan pohon, dan lainnya. Hal itu memiliki bahaya yang besar bagi kelangsungan hidup makhluk Allah yang ada di bumi seperti: hewan, tumbuhan, dan manusia bahkan mengancam keberlangsungan hidup mereka semua.

Ada di sebagian wilayah sering dikatakan dengan wilayah atau tempat atau daerah primitif, di sana ada sekelompok masyarakat yang mereka mempercayai bahwa adanya kekuatan besar yang kasat mata yang bertugas melindungi alam. Keyakinan dan kepercayaan mereka atas kekuatan ghaib ini menyebabkan berkembangnya sebuah gerakan-gerakan budaya atau biasa disebut dengan adat istiadat, yang kemudian budaya atau adat istiadat tersebut ditasbihkan oleh sebagaian yang lain sebagai agama. Adat istiadat atau budaya tersebut

3 Ahmad Muzakki, "Islam via a vis Orang Rimba: Studi Konsep Pendidikan Lingkungan Hidup Orang Rimba dalam Seloko Pesemian", Akademika, Vol. 19, No. 02, Juli - Desember 2014, h. 202. 
kemudian melahirkan sebuah gerakan ataupun ritual yang kemudian dianut dan dilestarikan oleh generasi satu kegenerasi lainya.

Bersama agama Allah layaknya agama dan kepercayaan serta keyakinan berkembang menjadi adat atau kebiasaan dimasyarakat hal ini yang sementara waktu mampu menahan keganasan oknumoknum manusia yang akan memperkosa alam secara brutal.

Adapun data-data yang digunakan dalam penelitian ini adalah data yang berupa kajian pustaka dari berbagai literatur yang berkaitan dengan permasalahan yang dibahas aktualisasi pendidikan Islam dalam pengelolaan lingkungan hidup: studi relasi antara pendidikan Islam dan budaya mistis dalam pelestarian lingkungan. Beberapa referensi yang digunakan adalah berasal dari buku pelajaran, jurnal ilmiah berbasis Open Journal System (OJS), dan artikel ilmiah yang bersumber dari internet.

\section{B. Lingkungan Hidup dalam Pelbagai Sudut Pandang}

\section{Lingkungan Hidup}

Lingkungan yaitu kombinasi antara keadaan fisik yang memuat keadaan sumber daya alam yang ada di bumi seperti tanah, air, energi surya, mineral, flora, dan fauna yang tumbuh dan berkambang di atas tanah maupun yang tumbuh dan berkembang di dalam lautan, dengan kelembagaan yang ada meliputi segala sesuatu ciptaan manusia seperti keputusan atau aturan bagaimana menggunakan lingkungan fisik tersebut dengan sebaik-baiknya. Lingkungan itu sendiri terdiri dari dua komponen yaitu komponen abiotik dan komponen biotik. ${ }^{4}$

Manusia hidup di bumi tidak berdiri sendiri, melainkan bersama dengan makhluk Allah lainya seperti: tumbuhan, hewan, dan lainnya. Makhluk hidup yang ada bukanlah hanya sekedar teman hidup, melainkan manusia, dan makhluk hidup lainya sangat berhubungan erat untuk melangsungkan kehidupan yang nyaman dan tentram serta saling memerlukan satu dengan yang

\footnotetext{
n.d.

4 Novianti Muspiroh, "Peran Pendidikan Islam dalam Pelestarian Lingkungan," 
lainya. Pada kenyataannya kita saling membutuhkan yaitu jika di bumi ini tidak ada hewan dan tumbuhan, maka manusia akan sulit untuk mendapatkan oksigen begitupun sebaliknya. Seyogyanya kita semua harus menyadari bahwa kitalah yang sangat memerlukan alam seperti tumbuhan dan hewan untuk kelangsungan hidup kita. Jadi, seharusnya kita bersikap baik kepada alam dengan menjaga alam dengan sebaik-baiknya.

Istilah lingkungan berasal dari bahsa Inggris yaitu environment dan bahasa arab al-bi'ah yang berarti yaitu sebuah kesatuan ruang yang di dalamnya terdapat beberapa benda seperti daya, kondisi, dan makhluk hidup termasuk manusia dan prilakunya. Ilmu yang mempelajari tentang lingkungan hidup adalah ilmu ekologi. Jadi ilmu lingkungan hidup yaitu sebuah ilmu yang mengkaji tentang lingkungan hidup seperti bagaimana melestarikan lingkungan hidup dengan baik, merawat serta melindungi keasrian lingkungan hidup. Lingkungan hidup mencakup lingkungan alam hayati, lingkungan alam non hayati, lingkungan buatan, dan lingkungan sosial yang memperngaruhi kelangsungan hidup manusia serta kesejahteraan manusia berserta mahkluk Allah lainya. ${ }^{5}$

Keanekaragaman merupakan sebuah ciri kemantaban sebuah sistem, semakin banyak dan semakin komplek serta beragam maka sistem tersebut dikatakan sebuah sitem yang mantab dan memiliki banyak makhluk hidup maka keadaan sistem itu mantab dan stabil, karena setiap komponen dan struktur akan mengisi stuktur masing-masing dan fungsinya dengan sebaik-baiknya.

5 Ara Hidayat, "Pendidikan Islam dan Lingkungan Hidup," Jurnal Pendidikan Islam 4, no. 2 (1 Desember 2015): 373, https://doi.org/10.14421/jpi.2015.42.373-389. 


\section{Pendidikan Islam dan Lingkungan Hidup}

Pendidikan Islam bersal dari istilah yang terjalin dari dua kata yaitu pendidikan dan Islam. Dalam hal ini, memilki kata kunci yaitu Islam yang memiliki fungsi sebagai kata sifat, penegas dan pemberi suatu ciri khas bagi kata pendidikan. Pendidikan Islam tersebut adalah sutu pendidikan yang memiliki ciri khas yaitu memiliki ciri yang Islami, berbeda dengan adanya konsep atau suatu model pendidikan yang lainnya. Istilah yang digunakan untuk menyebutkan pendidikan ada tiga macam yaitu ta'lim, tarbiyah, dan $t a^{\prime} d i b{ }^{6}$

Penggunaan kata ta'lim mengandung arti yaitu sebagai proses memberikan atau trasfer pengetahuan, pemahaman, tanggung jawab, serta pemberian amanah sehingga dalam proses tersebut terjadi pembersihan diri serta dilaksanakan dalam kondisi yang sudah siap untuk menerima hikmah serta dapat mempelajari segala sesuatu yang belum pernah diketahuinya dan berguna bagi dirinya dan orang lain.

Kata $t a^{\prime} d i b$ adalah bentuk masdar dari kata kerja Addaba yang mempunyai arti yaitu mendidik, melatih, memperbaiki, serta memberikan tindakan. Selain itu, istilah ta'dib yang berasal dari kata dasar Addaba yang mempunyai arti akhlak, sopan santun, serta budi pekerti. Pendidikan Islam yang dasarnya yaitu suatu usaha yang dilakukan guru kepada murid untuk melatih serta menanamkan akhlak mulia pada anak-anak, hak itu biasa disebut sebagai ta'dib.

Kata tarbiyah yaitu bentuk dasar dari kata kerja rabba yang berasal dari kata rabba-yarbuu yang memiliki pengertian dasar yaitu tumbuh dan berkembang. Berdasarkan hal tersebut dapat dikatakan bahwa kata tarbiyah mengandung pengertian dasar yaitu menumbuhkan serta mengembangkan. Dari ketiga uraian istilah yang mempunyai arti dan pengertian dasar yang memiliki

${ }^{6}$ Ali Mahsun, "Pendidikan Islam dalam Arus Globalisasi Sebuah Kajian Deskriptif Analitis," 2013 Vol. 8, (Desember). 
pengaruh atau arti saling berkaitan tersebut dapat digunakan untuk pendidikan dan digunakan secara bersama-sama serta cocok untuk konsep dalam pendidikan Islam.

Fungsi dari lingkungan hidup terhadap manusia yaitu yang pertama sebagai tata ruang bagi keberadaan manusia, seperti mencakup segi estetika dan fisika yang ada didalam diri manusia sebagai dimensi jasmani, rohani, dan kebudayaan. Manusia sendirilah yang mengembangkan kesadaran terhadap menjaga lingkungan. Namun, hanya sedikit manusia yang sadar untuk menjaga lingkungan hidup. Hal ini berdasarkan terungkapnya berbagai macam prilaku manusia yang selalu meningkatkan tekanan terhadap sifat alamiah lingkungan hidupnya. Sifat asli dan keanekaragaman dari alam tersbut diganggu sehingga terjadi halhal yang tidak diinginkan seperti lingkungan menjadi tercemar. Hal ini terjadi, karena sifat manusia yang ingin mengubah dan mengembangkan habitatnya agar meluas dan menjadi banyak.

Kedua, lingkungan hidup berfungsi sebagai penyedia segala kebutuhan yang dibutuhkan manusia. Sumber daya yang di hasilkan dari lingkungan menghasilkan energi dan sumber daya yang memenuhi segala kebutuhan manusia. Dalam QS. al-Hud ayat 617, Allah menjelaskan yang intinya Allah telah menciptakan manusia dari bumi (tanah) dan manusialah yang memakmurkan bumi tersebut. Jadi pada dasarnya manusia sudah mendapatkan tugas khusus dari Allah yaitu menjaga alam serta melestarikan alam tersebut.

Pendidikan Agama Islam merupakan suatu proses transfer pengetahuan dan nilai Islam kepada peserta didik melalui upaya pengajaran, pembiasaan, bimbingan, pengasuhan, pengawasan, pengarahan, pengembangan potensi-potensinya untuk mencapai keselarasan dan kesempurnaan hidup di dunia dan di akhirat,

7 Departemen Agama RI, Al-Quran Tajwid Dan Terjemah (Bandung: Cv. Penerbit Iponegoro, 2010). 
jasmani dan rohani serta kemampuan peserta didik untuk menjadi lebih baik lagi khusunya dalam hal agama. ${ }^{8}$

Pendidikan Islam disebut juga proses pembentukan setiap sikap individu berdasarkan ajaran agama Islam yang diwahyukan Allah kepada Nabi Muhammad SAW yaitu Al-Qur'an. Melalui proses dimana setiap individu dibentuk dan dibina agar dapat mencapai derajat yang tinggi sehingga ia mampu menunaikan tugasnya sebagai khalifah di muka bumi. Sebagai khalifah dimuka bumi ini manusia mempunyai tugas yang mulia yaitu menjaga bumi dan seisinya serta lingkungan agar tetap asri dan tidak ada lagi kerusakan alam yang diakibatkan oleh ulah manusia.

Etika atau sikap dalam pengelolaan lingkungan dalam Islam yaitu mencari keselarasan atau keseimbangan dengan alam sehingga manusia tidak hanya memikirkan kepentingan diri sendiri akan tetapi manusia juga mementingkan kehidupan alam sekitar serta menjaga lingkungan dari kerusakan. Setiap kerusakan yang terjadi terhadap lingkungan harus dilihat sebagai perusakan terhadap manusia itu sendiri karena sudah tugas manusialah alam ini dijaga bukan dirusak dan dimanfaatkan semau manusia itu sendiri.

Pendidikan Agama Islam yang didalamnya terdapat berbagai materi-materi tentang lingkungan hidup, menjadi investasi strategis untuk mewujudkan lingkungan yang hijau dimana salah satu tujuannya yaitu membentuk masyarakat agar cinta terhadap lingkungan serta peduli terhadap kelestarian lingkungan. Menciptakan masyarakat yang suka akan keindahan serta melestarikan lingkungan adalah tantangan yang besar. Sekarang banyak sekali manusia yang bersifat apatis dan terlalu mementingkan dirinya sendiri tanpa memperhatikan kehidupan alam dan kehidupan orang lain. Menumbuhkan kesadaran masyarakat harus dilakukan karena bisa jadi masyarakat yang

${ }^{8}$ Yasin, "Implementasi Pendidikan Agama Islam Berbasis Konservasi Lingkungan Hidup Dalam Membentuk Karakter Siswa," 2017, Maret. 
suka merusak dan mengeksploitasi alam dengan paksa mereka tidak tahu bahkan mungkin mereka tidak paham mengenai konsep melestarikan lingkungan adalah tugas mulia manusia sebagi khalifah atau pemimpin di bumi ini.

\section{Lingkungan Hidup dalam Konsepsi Budaya Animisme}

Kebudayaan atau budaya yaitu pada dasarnya merupakan sebuah konsep sosial, yang sebenarnya sebuah kebudayaan tersebut akan selalu memiliki fungsi karena dengan kebudayaan terebut dapat menjadikan suatu cara untuk melestarikan serta menjaga keberlangsungan kehidupan mereka. Suatu Budaya akan mati atau punah apabila semua manusia mati, hal ini sangat berkaitan dengan fakta yang menyebutkan bahwa suatu kebudayaan itu dinamis dan relatif. Oleh karena itu, pada dasarnya pola pembentukan budaya atau suatu kebudayaan didasari oleh sejarah, pengalaman, dan lingkungan. ${ }^{9}$

Animisme berasal dari bahasa latin yaitu anima atau animus yang berarti nafas atau jiwa. Dan isme yang berarti paham atau kepercayaan. Sehingga animisme secara bahasa yaitu suatu paham atau kepercayaan yang meyakini bahwa setiap benda yang hidup atau yang mati mereka mempunyai jiwa. Animisme adalah kepercayaan segala sesuatu yang ada itu, seperti pohon, lembah sungai gunung, dan lain sebagainya memiliki ruh dan mereka hidup. Animisme juga diartikan sebagai kepercayaan terhadap makhluk-makhluk astral yang berkaiatan dengan tubuh atau jasad. Kemudian makhluk astral itulah yang membentuk yang dibentuk kepribadian. ${ }^{10}$

Pada dasarnya kepercayaan yang ada pada seseorang terhadap setiap benda yang memiliki ruh atau jiwa yang ada di dalam benda hidup maupun benda mati, hal ini tidak sepenuhnya

\footnotetext{
9 Johan Purnama, Agama dan Budaya Lokal di Indonesia (Jakarta Selatan: Agama dan Budaya Lokal di Indonesia, 2015).

10 Widagdo, "Relasi Alam dan Agama (Sebuah Upaya Penyelarasan antara Budaya Mistis dengan Pelestarian Lingkungan)."
} 
berbeda dengan ajaran agama Islam. Di dalam agama Islam menyatakan bahwa semua makhluk hidup yang ada di dunia adalah menyembah dan bertasbih kepada Allah Tuhan Semesta Alam. Perbedaan yang terdapat dari keyakinan ini adalah hanyalah dari segi penyembahan. Dimana agama islam tidak membenarkan jika pemeluknya mendukan kepada selain Allah. Artinya penyembahan hanya dilakukan untuk Allah, tidak ada tempat untuk memohon dan meminta selain kepada Allah yang menguasai segala jagat raya.

Animisme dapat dikatakan atau digolongkan sebagai agama atau kepercayaan yang primitif, karena mereka penganut paham animisme lebih cenderung yakin dan percaya kepada ruh yang ada dibenda-benda yang mereka anggap sebagai bentuk penghormatan dibandingkan mereka percaya akan kekuasan Allah Tuhan semesta alam. Meskipun terjadi hal demikian yang di anggap bahwa animisme adalah kepercayaan orang-orang yang primitif, namun terdapat fonomena dimana bukan hanya orang primitif yang menganut paham animisme. Penggunaan dari istilah itu sering disebut agama-agama primitif.

Dalam kontek agama primitif, para penganut paham animisme mempercayai dan meyakini sepenuhnya bahwa jiwa-jiwa yang terdapat pada benda hidup ataupun mati dapat memberikan manfaat dan keburuntungan serta kemuliaan bagi mereka. Sehingga untuk memperoleh manfaat dan "tuah" dari ruh-ruh yang mereka yakini tersebut, maka melakukaan penyembahan, memberikan sesajen, dan ritual-ritual lainya untuk mendapatkan "kebarokahan" serta terhindar dari kemurkaan-kemurkaan rohroh tersebut.

Meski demikian, terdapat sisi positif dari agama primitif terebut yaitu mereka cenderung melindungi alam dan melahirkan sikap menghormati serta sikap sopan terhadap benda-benda yang ada di alam. Cara seperti ini dapat digunakan untuk melindungi alam dari oknum-oknum yang tidak bertanggung jawab dan ingin mengekploitasi alam secara paksa. 
Mistis atau animisme merupakan sebuah prilaku yang dapat dikatakan primitif untuk ukuran zaman sekarang ini. Namun, ada beberapa dampak positif dari sifat mistis atau animisme tersebut yaitu melahirkan sebuah bentuk kecemasan atau ketakutan akan kekuasaan alam yang jarang diperoleh oleh ajaran lain. Ketika ada seseorang penganut ajaran animisme tinggal di alam, maka mereka akan cenderung sopan memperlakukan alam juga mereka takut dan khawatir ketika mereka bertindak tidak sopan atau kurang ajar terhadap alam. Sebab itulah, ruh dan jiwa-jiwa pada benda-benda yang mereka yakini pada alam tersebut akan marah. Mereka yakin hal itu akan menimbulkan kesialan bahkan bahaya bagi kehidupan mereka. ${ }^{11}$

Namun dilihat dari sisi lain, ada dampak negatifnya yaitu ketika masyarakat mengkultuskan untuk menyembah maka ada pembatasan tingkah laku manusia terhadap alam. Sehingga, masyarakat cenderung akan memiiki sifat apatis, yang mereka menyerahkan segala sesuatu kepada alam secara penuh dan pada akhirnya sifat apatis ini menghasilkan budaya yaitu penyembahan terhadap alam.

Sikap yang mengabaikan tuntunan atau perintah agama, akan memiliki dampak buruk bagi kehidupan manusia, seperti terjadinya musibah paceklik, hasil ikan laut yang tidak banyak, hilangnya rasa aman pada manusia masyarakat serta lingkungan, dan lainnya. Hal itu disebabkan karena ulah manusia yang durhaka dan tidak menuruti perintah-perintah Allah, sehingga Allah mengingatkan mereka melalui musibah tersebut agar manusai sadar dan kembali kepada jalan yang benar. ${ }^{12}$

Pengelolaan dan pemeliharaan alam adalah satu tugas pokok manusia, yang harus menjaga dan melestarikan alam dengan sebaik-baiknya. Hal ini juga dijelaskan dalam salah satu firman

11 Jumarddin La Fua, "Aktualisasi Pendidikan Islam dalam Pengelolaan Lingkungan Hidup menuju Kesalehan Ekologis," Al-Ta'dib 7, no. 1 (2014): 19-36.

12 Widagdo, "RELASI ALAM DAN AGAMA (Sebuah Upaya Penyelarasan antara Budaya Mistis dengan Pelestarian Lingkungan).” 
Allah dalam surat Hud ayat 61 yang artinya Allah menciptakan manusia dari bumi (tanah) dan Allah juga menjadikan kamu (manusia) sebagai pemakmur bumi tersebut, artinya manusialah yang bertugas memuliakan serta memak-murkan bumi tersebut. ${ }^{13}$ Ketika setiap jiwa atau manusia mampu atau dapat mengelola serta memilihara alam dan memakmurkan alam secara benar dan sesuai dengan yang dibutuhkan tanpa mengekploitasi berlebihan maka sumber daya alam yang diberikan Allah kepada manusia akan menjadi salah satu sumber kesejahteraan yang didapat bagi manusia itu sendiri, serta makhluk lainnya.

Salah satu hasil alam yang sangat bermanfaat bagi kelangsungan kehidupan manusia serta makhluk hidup adalah air. Selain berguna, bagi manusia air juga sangat bermanfaat bagi kelangsungan hidup tumbuhan, seperti menyuburkan tanaman. Air merupakan sumber kebutuhan primer bagi manusia dan makhluk hidup lainnya karena dengan air tersebut mereka dapat bertahan hidup sampai sekarang ini. Terdapat banyak potensi air yang dapat dimanfaatkan bagi manusia diantaranya air dapat disulap dan dijadikan sebagai salah satu alat penghasil energi listrik. Jika air dirawat dan dikelola dengan baik, maka akan banyak manfaatnya bagi manusia, sebagai bahan penghasilan manusia yaitu air digunakan sebagai salah satu objek wisata yang menawan yang dapat menghasilkan keuntungan bagi manusia, seperti pembuatan air terjun, waduk buatan, dan lain sebagainya.

Sebagai wakil Tuhan yang ada di bumi manusia diamanatkan dan diberi tugas agar menggunakan segala sumber daya alam secara baik dan benar dan tidak memanfaatkan secara berlebihan. Melalui akal dan fikirannya, manusia dapat bersikap inovatif dam kreatif untuk menciptakan dan memanfatkan segala sumber daya alam yang ada dibumi untuk kebuhan manusia bersama dengan makhluk hidup lainya. Namun, apabila manusia bersikap over atau berlebihan dalam memanfaatkan sumber daya alam yang ada di

13 Departemen Agama Ri, Al-Quran Tajwid Dan Terjemah. 
bumi, hal tersebut jika dilakukan maka akan merugikan manusia itu sendiri, bukan hanya manusia tetapi meluas merugikan makhluk hidup lainnya. Sikap manusia dalam memanfaatkan sumber daya alam ini tergantung dengan seberapa besarnya rasa tanggung jawab manusia sebagai khalifah atau wakil Tuhan yang ada di bumi. Semakin besar rasa tanggung jawab manusia dalam mengelola sumber daya alam, maka akan semakin baik hasil dan maksimal pemanfaatan sumber daya alam ini.

\section{Kepedulian Agama Terhadap Kelestarian Alam}

Sebagaimana telah diungkapkan pada point sebelumnya, hubungan antara manusia dengan alam sangat begitu erat, sehingga segala sesuatu apa yang dilakukan manusia terhadap alam, maka akan berdampak juga bagi manusia itu sendiri. Agama yang ditetapkan Allah kepada manusia adalah salah satu cara untuk mengontrol segala sesuatu yang diperbuat manusia. Begitu juga dalam agama, tidak sedikit perintah Allah agar manusia bersikap bijaksana kepada alam. Di antara sumber ajaran agama Islam yaitu Al-Qur'an yang berisikan seruan atau ajakan kepada manusia untuk menjaga alam dan tidak sewenang-wenang kepada alam. Salah satu ajarannya tercantum pada al-Quran surah al-A'raf yang isinya yaitu Allah menyeru kepada manusia agar manusia tidak melakukan kerusakan di muka bumi, setelah Allah memperbaikinya, dan Allah menyuruh manusia untuk berdoa dengan rasa takut dan penuh harap kepada Allah agar dikabulkan doanya. Dan sesungguhnya rahmat Allah sangat dekat kepada orang-orang yang berbuat baik. ${ }^{14}$

Hal ini merupakan sebuah larangan kepada manusia, agar manusia tidak berbuat atau melakukan kerusakan terhadap alam, kepada sesama manusia, ataupun kepada makhluk hidup lainnya. Alam jagad raya ini telah ditetapkan sedemikian seimbang, harmonis, serasi dan bermanfaat untuk kebutuhan makhluk Allah

14 Departemen Agama RI. 
yang ada di bumi. Ketika keharmonisan dan keserasian tersebut hilang karena ulah manusia, maka bencana akan turun melanda manusia dan makhlukNya. Sebagai wakil Tuhan atau khalifah di dunia, maka sangatlah wajar jika larangan merusak dan mengeksploitasi secara berlebihan alam dan merusak keharmonisan dan keserasian alam itu ditujukan kepada manusia, karena manusia adalah khalifah. Allah yang bertugas mengayomi, melindungi, dan mengelola alam dengan cara sebaik-baiknya.

\section{Pergumulan Pendidikan Islam dan Pelestarian Lingkungan}

Hasil yang diperoleh dari penelitian yang berjudul Aktualisasi Pendidikan Islam dalam Pengelolaan Lingkungan Hidup: Studi Relasi Antara Pendidikan Islam dan Budaya Mistis dalam Pelestarian Lingkungan dari berbagai studi pustaka yang telah peneliti teliti adalah sebagai berikut:

Pertama, penelitian yang ditulis oleh Deni Miharja tentang Wujud Kebudayaan Masyarakat Adat Cikondang dalam Melestarikan Lingkungan. ${ }^{15}$ Berdasarkan penelitian tersebut diperoleh hasil bahwa sekelompok masyarakat adat yang mampu bertahan hidup di tengah arus modernisasi dan berkembangnya zaman yang sangat pesat. Pada penelitian tersebut menunjukkan bahwa bertahan hidup dengan konsep kehidupan yang sangat sederhana yang dikembangkannya, yaitu dengan cara mereka menjaga lingkungan alam tempat tinggal mereka dengan sekelompok masyarakat adat yang sampai saat ini masih terselamatkan dengan musibah yang sering melanda di desa mereka.

Masyarakat adat yang ada di Desa Cikondang dengan banyak kebudayaan yang dimilikinya mampu merealisasikan fungsinya dalam wujud budaya dan diaplikasikan dalam bentuk aktifitas atau tradisi ritual yang mereka yakini bisa mengandung nilai bagi keberlangsungan kehidupan masyarakat adat itu sendiri. Masyarakat adat masih mampu bertahan di era globalisasi ini dan yang masih

15 Deni Miharji, "Wujud Kebudayaan Masyarakat Adat Cikondang dalam Melestarikan Lingkungan," September 1 (2016): 51-61. 
mampu menjalankan ketiga wujud kebudayaan dalam melestarikan lingkungan alam. Hal ini dapat dilihat pada masyarakat adat Cikondang yang berada di Desa Lamajang Kecamatan Pangalengan Kabupaten Bandung.

Masyarakat Cikondang biasa dikenal dengan masyarakat yang memiliki etnis Sunda dan dapat dikategorikan masyarakat Cikondang sebagai salah satu komunitas masyarakat adat, karena masyarakat Cikondang sampai saat ini masih menjalankan dan berpegang teguh terhadap ajaran leluhurnya atau nenek moyangnya. Dan masyarakat Cikondang sendiri mayoritas beragama Islam. Artinya di sini pada masyarakat Cikondang terdapat proses pencampuran antara agama Islam dengan budaya Sunda yang berlangsung dalam segala aspek kehidupan mereka. Hal yang ada dan sangat menojol pada masyarakat adat Cikondang yaitu kegigihan dan semangat masyarakat adat Cikondang dalam melestarikan serta memanfaatkan lingkungan yang ada sekitar daerah mereka untuk melangsungkan kehidupannya. Kondisi seperti ini bisa dilihat pada masyarakat adat Cikondang ketika musim hujan, di daerah mereka tidak terkena longsor, bahkan mereka dapat memanfaatkan sumber air secara maksimal untuk kebutuhan pertanian mereka. Padahal posisi tempat tinggal masyarakat Cikondang berada di perbukitan Gunung Tilu. Begitupun ketiga musim kemarau tiba masyarakat adat Cikondang tidak perlu khawatir akan kekurangan air walaupun secara strategis tempat tinggal mereka berada di perbukitan penggunangan.

Dalam hal mewujudkan kebudayaan yang sifatnya aktifitas kegiatan, masyarakat adat Cikondang yang memiliki kaitan dengan peletarian lingkungan dan bentuk kepedulian masyarakat Cikondang terhadap lingkungan. Masyarakat Cikondang ada sebuah tradisi untuk kegiatan tersebut, ada yang terjadwal secara kontinue yang secara otomatis dilakukan selama setahun sekali atau dua kali.

Diantara tradisi masyarakat Cikondang tersebut antara lain;

a. Tradisi Wuku Taun.

Tradisi Wuku Tuan merupakan upacara yang dilakukan dengan bertepatan tahun baru Islam yaitu tahun baru hijriah. 
Upacara ini diperingati setiap tanggal 15 Muharam. Dilakukan upacara ini dengan harapan melepas tahun lalu dengan segala kenangan dan kekurangannya serta menyambut tahun baru agar di tahun baru itu dapat lebih baik dari tahun yang sebelumnya. Upacara adat Cikondang ini dilaksanakan secara besar-besaran, khusus dilakukan oleh masyarakat Lumejeng khusunya dan umumnya diikuti oleh masyarakat Desa Lamajang pada umumnya.

b. Tradisi Ngaruat Lembur (Hajat Lembur).

Kegiatan ini dilakukan oleh masyarakat adat Cikondang dalam bentuk mengadakan selametan yang dilakukan oleh masyarakat setempat yang bertujuan untuk melindungi keselamatan kampung halaman mereka. Tradisi Ngaruat Lembur adalah salah satu adat istiadat yang turun temurun diturunkan dan dilaksanakan oleh masyarakat adat Cikondang yang dimana pada prosesnya masyarakat meminta kepada Allah Swt agar lingkungan yang dihuni atau ditempati mendapatkan keberkahan serta keselamatan hidup.

c. Tradisi Ngaruat Bumi yaitu ngaruat kandang hayam.

Dalam tradisi ini masyarakat adat Cikondang telah mempersiapkan segala sesuatunya yang akan menjadi pelengkap ngaruat bumi, dari persiapan awal, proses tradisi yang dilakukan sampai setelah tradisi tersebut dikerjakan. tujuan dari ngaruat bumi dan juga kandang hayam adalah sebagai ungkapan wujud syukur kepada Allah Swt. Yang dikemas dan dilaksanakan dalam bentuk tradisi yang masih dilestarikan oleh masyarakat adat Cikondang.

d. Tradisi Ruat Solokan

Suatu tradisi yang pada prinsipnya salah satu upaya untuk melestarikan dan melindungi selokan yang digunakan sebagai saluran air yang digunakan oleh masyarakat untuk mengairi sawah dan kolam serta digunakan untuk yang lainnya, jadi apa bila selokan atau aliran air terjaga dengan baik akan kebersihannya, maka hal itu akan memberikan banyak manfaat bagi kelangsungan hidup masyarakat Cikondang. Pada pelaksanaan tradisi begitu terlihat penerapan nilai-nilai ajaran agama Islam, yang dimana 
acara dimulai dengan bacaan tawashul dan doa-doa yang dibacakan. Adapun tujuan dari ngeruat solokan itu sendiri yaitu sebagai ungkapan rasa syukur kepada Allah swt.

e. Tradisi Ruat Hajat

Salah satu tradisi yang masih dijalankan oleh masyarakat Cikondang yaitu sebagai salah satu wujud kebudayaan yang dilaksanakan dalam bentuk aktifitas terdapat pada tradisi ngaruat hajat. Pada tradisi ini, masyarakat sangat antusias dalam melakukan berbagai aktifitas, dari mulai persiapan ritual, proses ngaruat hajat, sampai selesainya acara tersebut. Tujuan dari ngaruat hajat yaitu ungkapan rasa syukur kepada Allah Swt.

\section{f. Tradisi Upacara Pertanian}

Upacara yang dilaksanakan oleh para petani. Dengan mempersiapkan berbagai bahan yang akan digunakan untuk pelaksanaan upacara. Diadakan upacara ini yaitu dengan tujuan agar mereka para petani mendapatkan hasil yang melimpah ruah serta dalam bertani tidak ada halangan suatu apapun.

g. Tradisi Upacara Hajat Paralon

Tradisi ini biasa disebut dengan hajat atau selamatan yaitu salah satu tradisi yang dilaksanakan di tempat pedesaan atau sebuah Kampung Cikondang di Desa Lamajang Kecamatan Pangalengan di Kabupaten Bandung. Upacara ini dilakukan turun temurun diturunkan dari generasi ke genarsi penerusnya. Tujuan diadakan upacara hajat ini yaitu sebagai salah satu ungkapan rasa syukur terhadap nikmat yang telah Allah berikan serta terhindarnya masyarakat dari segala mara bahaya yang datang dari alam ataupun dari manusia lain. Wujud kebudayaan masyarakat Cibondang yang dilakukan dalam bentuk artefak yaitu bisa dilihat dari adanya hutan keramat, yang dipercayai dan yang menjadi simbol bagi keutuhan alam, serta adanya rumah adat yang digunakan sebagai simbol keutuhan pada adat masyarakat Cikondang.

Kedua, yaitu penelitian yang dilakukan oleh Afif Andi Wibowo tentang Persepsi Masyarakat Terhadap Mitos Air Tiga Rasa di 
Lingkungan Makam Sunan Muria Kabupaten Kudus. ${ }^{16}$ Mitos yang di percaya oleh masyarakat di Kabupaten Kudus yang berada di lingkungan makam Sunan Muria yaitu mereka mempercayai bahwa di situ terdapat air yang memiliki tiga rasa yang diwariskan oleh masyarakat Japan melalui lisan dari generasi ke generasi selama bertahun-tahun, tetapi hal itu masih ada dan tetap dipertahankan serta masih dipercaya sampai sekarang oleh masyarakat sekitar. Berdasarkan penelitian tersebut, air tiga rasa ini mempunyai tiga mata sumber air, yang dari ketiga sumber air tersebut mempunyai rasa yang berbeda-beda. Adapun ketiga rasa itu adalah; Sumber air yang pertama memiliki rasa tawar, sumber air yang kedua memilki rasa seperti sprite, dan sumber air ketiga memiliki rasa seperti arak. Hal inilah yang menjadikan munculnya persepsi dan pandangan masyarakat mengenai air tiga rasa dari masyarakat yang berada Desa Japan dan sekitarnya.

Mitos air tiga rasa yang berada di lingkungan makam Sunan Muria di Kabupaten Kudus masih sangat dipercaya sampai sekarang, alasan masyarakat masih sangat percaya akan hal ini adalah adanya perbedaan rasa dari ke tiga sumber mata air terbut, air tiga rasa merupakan salah petilasan Syekh Hasan Shadily yang sampai sekarang sudah menjadi keyakinan dan kepercayaan masyarakat untuk mempercayai mitos air tiga rasa secara turun-temurun sehingga menjadi budaya. Persepsi yang ada pada masyarakat terhadap mitos air tiga rasa di lingkungan makam Sunan Muria terbagi dalam beberapa kelompok yaitu kelompok sosial dalam masyarakat Japan serta masyarakat luar Japan yang memiliki kepercayaan dan keyakinan pada mitos air tiga rasa diantaranya yaitu laki-laki dan perempuan, dari segi usia yang mempercayai akan hal itu yaitu masyarakat yang sudah tua, dari segi pekerjaan mereka adalah seorang petani dan pedagang, dari segi pendidikan mereka yaitu tamatan Sekolah Dasar (SD); dan mereka percaya bahwa terdapat

16 Afif Andi Wibowo, "Persepsi Masyarakat Terhadap Mitos Air Tiga Rasa di Lingkungan Makam Sunan Muria Kabupaten Kudus," Juli, 2011. 
pengaruh mitos air tiga rasa di lingkungan makam Sunan Muria di Kabupaten Kudus terhadap masyarakat sekitar yaitu baik bagi pemilik warung, penyedia jasa ojek, maupun jasa parkir yang ada disekitar makam tersebut.

Dengan adanya mitos atau kepercayaan tersebut masyarakat yang ada disekitar makam Sunan Muria, selalu menjaga alam tersebut dengan sebaik-baiknya karena mereka menyakini bahwa hal itu adalah anugrah yang diberikan Tuhan kepada mereka melalui adanya tiga mata air yang berada didekat makam Sunan Muria dengan memiliki rasa yang berbeda. Mereka selalu merawat untuk melestarikan budaya dan kepercayaan leluhur mereka. Banyak pengunjung yang tidak berasal dari daerah Kabupaten Kudus tersebut, mereka jauh-jauh datang ke Kudus untuk merasakan manfaat dari air tiga rasa tersbut. Mereka meyakini bahwa ini adalah anugrah yang diberikan Allah kepada alam jadi mereka harus mensyukuri serta menjaga alam agar tetap terjaga kesuciannya dan kebermanfaatnaya bagi masyarakat pada umumnya.

Ketiga, penelitian yang dilakukan oleh Kastolani dan Abdullah Yusuf tentang Islam Dan Budaya Lokal (Studi Tentang Tradisi Nyadran di Desa Sumogawe Kecamatan Getasan Kabupaten Semarang). ${ }^{17}$ Penelitian tersebut menghasilkan beberpa hal, yaitu:

a. Pandangan yang dilakukan masyarakat terhadap memaknai sebuah tradisi nyadran merupakan salah satu ungkapan refleksi sosial keagamaan. Misalnya mereka menziarahi salah satu makam para leluhur sebagai cara atau bentuk pelestarian yang dilakukan oleh masyarakat sekitar sebagai warisan tradisi serta budaya para nenek moyang yang harus mereka jalankan.

b. Proses ritual yang dilakukan oleh masyarakat. Dalam pelaksanaan acara ritual nyadran di Desa Sumogawe yaitu tiga hari sebelum menjelang pelaksanaan nyadran, masyarakat Sumogawe Getasan

17 Abdullah Yusof, "Relasi Islam Dan Budaya Lokal: Studi Tentang Tradisi Nyadran Di Desa Sumogawe Kecamatan Getasan Kabupaten Semarang," IAIN Tulungagung Research Collections 4, no. 1 (n.d.). 
mengadakan sebuah rutual yaitu nyekar serta melaksanakn salah satu tradisi manganan atau kondangan.

c. Dampak dari budaya atau tradisi nyadran yaitu masyarakat dapat merasakan Sumogawe. Acara tersebut adalah sebagai wujud balas jasa atas pengorbanan yang dilakukan oleh para leluhur baik secara material maupun yang dilakukan secara non-material, hingga merka menjadi salah satu orang yang sukses. Dalam melestarikan tradisi ini yang merupakan salah satu wujud pelestarian budaya adiluhung sebagai peninggalan nenek moyang, terdapat beberapa manfaat kearifan yang dirasakan dalam prosesi tradisi nyadran yang masih relevan dengan konteks kekinian. Selain itu, tradisi nyadran menjelma menjadi sebuah ajang silaturahmi bagi masyarakat sekitar.

Keempat, penelitian yang telah dilakukan Napsiah tentang Kontekstualisasi Kepercayaan Warga Lokal dalam Menjaga Lingkungan Gunung Merapi. ${ }^{18}$ Dari penelitian tersebut dapat diketahui bahwa gunung merapi merupakan salah satu sumber penghidupan yang dirasakan oleh warga sekitar mulai dari lahir, remaja, dewasa sampai meninggal dan hingga diteruskan oleh generasi berikutnya. Selama dalam masa atau siklus kehidupan, masyarakat selalu menjaga keharmonisan, ketentraman dan kenyamanan dengan manusia atau sering disebut dengan hablumminnanas serta menjaga keharmonisan lingkungan atau disebut dengan mangku bumi.

Supaya tidak terjadi bencana alam yang akibatkan oleh ulah oknum yang tidak bertanggung jawab atau kepentingan kelompokkelompok tertentu, berbagai cara dilakukan oleh masyarakat disekitar gunung berapi unutk melindungi alam tersebut, salah satu upaya yang dilakukan oleh masyarakat sekitar untuk menjaga dan melindungi lingkungan baik dengan cara menggunakan pengetahuan lokal dan bahkan dengan cara menggunakan pergerakan lokal. Sistem yang digunakan oleh masyarakat lokal yang digunakan untuk menjaga

18 Napsiah Napsiah, "Kontekstualisasi Kepercayaan Warga Lokal dalam Menjaga Lingkungan Gunung Merapi," Kontekstualita 31, no. 1 (2017): 37-54. 
lingkungan di Jawa ada beberapa filosofi yang dilakukan yaitu niteni, niroake, dan nambahi. Niteni yaitu salah satu upaya yang digunakan untuk mengenali lebih dalam dari berbagai kejadian alam. Niroake yaitu sebuah simulasi yang digunakan untuk melakukan langkah selanjutnya dari hasil yang diperoleh melalui kegiatan niteni dengan cara berupaya menirukan atau menandai tanda-tanda kejadian alam yang sudah terjadi dan yang sudah dialami untuk keselamatan bersama, yang biasanya dapat berwujud sebagai peringatan dini terhadap salah satu bencana seperti banjir dan tanah longsor, masyarakat melakukan tindakan yaitu dengan cara menanam pohon dan memeliharanya. Sedangkan yang dimaksud dengan nambahi yaitu sebuah upaya yang memberi nilai tambah dalam menyikapi setiap kejadian alam atau bencana alam yang telah dikuasai cara penanggulangan serta bisa ditirukan.

Kelima, penelitian yang dilakukan oleh Muhibbatul Hasanah tentang Mitos Ikan Lele: Studi Deskriptif Masyarakat Desa Medang, Kecamatan Glagah, Kabupaten Lamongan. ${ }^{19}$ Dari hasil penelitian tersebut diketahui bahwa terdapat sebuah zaman modernisasi yang akan memberikan dampak pada pola pikir masyarakat. Hal ini seharusnya menjadikan masyarakat berbanding lurus dengan kemampuan rasionalnya. Namun pada kenyataannya, masih terdapat masyarakat modern yang meyakini mitos-mitos seperti yang terjadi di Desa Medang, Kecamatan Glagah, Kabupaten Lamongan yang masyarakatnya mempercayai adanya mitos ikan lele. Penelitian ini juga menunjukkan bahwa masih banyak masyarakat yang mempercayai adanya mitos ikan lele, ada beberpa faktor yang mempengaruhinya yaitu faktor agama, faktor kepercayaan yang diyakini oleh masyarakat, faktor keluarga yang sudah ditanamkan sejak lahir mengenai mitos ikan lele, dan faktor masyarakat yang melakukan sebuah ritual ziarah kubur yang dilaksanakan pada setiap hari Jum'at Pon. Masyarakat memaknai mitos ini sebagai cara untuk

19 Muhibbatul Hasanah, "Mitos Ikan Lele: Studi Deskriptif Masyarakat Desa Medang, Kecamatan Glagah, Kabupaten Lamongan," Juli-Desember II (2013): 157-156. 
lebih mendekatkan diri pada yang kuasa, selain kepercayaan atas mitos ikan lele juga dimaknai oleh masyarakat sekitar sebagai media pendidikan sebagai salah satu cara untuk menghormati jasa para tokoh dalam menyebarkan ajaran agama Islam.

Keenam, penelitian yang dilakukan oleh AA Kusumadinata tentang Proses Enkulturasi Dalam Budaya Entas-Entas, Praswala Gara, dan Pujan Kapat (Sistem Sosial Lokal: Antar Etnis Kabupaten Probolinggo). ${ }^{20}$ Hasil penelitian ini menunjukkan bahwa masyarakat di Tengger memiliki salah satu budaya yang sangat menarik dan unik yang masih terjaga dan masih terwat dengan baik. Meskipun terdapat beberapa faktor eksternal yang sanagat mempengaruhi intensitas tinggi kegiatan pariwisata, ada beberapa tradisi atau kebudayaan yang masih dilestarikan dan dijaga dengan baik oleh masyarakat Tengger.

Adapun beberpa tradisi yang masih dilakukan hingga saat ini antara lain; entas-entas, praswala gara, dan pujan kapat. Tradisitradisi tersebut sangat berlaku bagi masyarakat dengan proses komunikasi yang baik terhadap sesama masyarakat tengger. Hasil penelitian ini adalah menunjukkan bahwa adanya upacara adat di masyarakat Tengger yang pada umumnya dalam melaksanakan upacara dibagi menjadi beberpa kelompok yaitu kelompok orangorang yang mengenai jenis ruang lingkup keluarga dan kelompok ruang lingkup desa. Jenis pola komunikasi yang dilaksanakan atau dipraktekkan di kalangan lingkungan masyarakat Tengger merupakan salah satu hubungan vertikal, dimana seorang pemimpin atau beberpa kelompok terhormat yang memiliki posisi atau kedudukan penting dan mereka ditaati oleh masyarakat bawah atau masyarakat biasa, yang merupakan salah satu refleksi dari paternalistik budaya yang masih dipraktekkan dan dilaksanakan. Jenis Pola semacam ini dapat di komunikasi dan dapat dilihat di dalam beberapa proses belajarmengajar yang dilaksanaknn baik pada forum formal atapun forum nonformal sera ritual mengenai kelompok serta alokasi posisi.

${ }^{20}$ Ali Alamsyah, "Proses Enkulturasi Dalam Budaya Entas-Entas, Praswala Gara, Dan Pujan Kapat (Sistem Sosial Lokal: Antar Etnis Kabupaten Probolinggo)," Jurnal Komunikatio 1, No. 1 (2017). 
Ketujuh, penelitian yang dilakukan oleh Kholid Karomi tentang Tuhan dalam Mistik Islam Kejawen (Kajian atas Pemikiran Raden Ngabehi Ranggawarsita). ${ }^{21}$ Penelitian ini mendeskripsikan jika pada masyarakat Jawa yang terkenal dengan masyarakatnya yang religious dan agamis. Namun, salah satu di antara mereka terdapat beberapa golongan yang memiliki pandangan yang sinkretis. Dalam artian bahwa mereka lebih cenderung mengkompromikan atau memadukan hal-hal yang agak berbeda bahkan bertentangan dengan ajaran agama Islam. Sinkretis yaitu suatu anggapan bahwa mereka lebih cenderung berpandangan tidak mempersoalkan atau memperdulikan mengenai benar atau salah dalam melaksakan agama, murni, suci atau tidaknya sebuah agama, sehingga mereka menanggapi bahwa semua agama dianggap dan dilihatnya benar.

Selanjutnya, Raden Ngabehi Ranggawarsita merupakan salah satu tokoh yang mewakili pandangan tersebut. Beliau yang dibesarkan melalui proses akulturasi dua tradisi yang besar, yaitu tradisi keIslaman dan tradisi kejawen. Tradisi keislaman yang diperoleh beliau melalui perjalanan hidupnya. Selama tinggal di pesantren dan tradisi kejawen diperolehnya melaui lingkungan Keraton Surakarta. Akulturasi yang terjadi dua tradisi yang beda pemikiran besar tersebut berakibat kepada pembentukan pola fikirnya yang memiliki corak kejawen sekaligus memiliki corak keislaman. Maka, sebuah konsep ketuhanan yang beliau gagas tidak sepenuhnya memenuhi nilai-nilai dasar Islam, yaitu tauhid. Suatu paham yang digagas oleh Rangga warsita yaitu Manunggaling Kawula-Gusti menunjukkan sebuah pandangan yang sinkretis dan akulturis yaitu sebuah pandangan antara dirinya sebagai seorang muslim serta pandangan dirinya sebagai penganut kejawen atau kebatinan.

Kedelapan, penelitian yang dilakukan oleh Tasdyanto tentang Budaya Lingkungan Hidup Komunitas Kota di Yogyakarta. Adapun hasil penelitannya menunjukkan bahwa dalam sebuah komunitas

21 Kholid Karomi, "Tuhan dalam Mistik Islam Kejawen (Kajian atas Pemikiran Raden Ngabehi Ranggawarsita)," Kalimah 11, no. 2 (2013): 287-304. 
yang meiliki atau brlatar belakang berpendidikan, bisnis, kraton serta berlatar belakang kampung, terjadi dinamika dalam masalah budaya lingkungan hidup dalam hal pola pikir serta perilaku lingkungan hidup. Dinamika terhadap budaya lingkungan hidup yang disebabkan oleh perkembangan ilmu pengetahuan serta ilmu teknologi, ekonomi serta perubahan budaya. Terdapat fakta empiris serta adanya faktor yang mempengaruhi dan menyebabkan masalah dinamika tersebut. Dinamika masalah tersebut terdapat konsep budaya tradisional serta budaya rasional. Konstruksi terhadap hasil penerapan model budaya lingkungan hidup (ecoculture) meliputi meliputi berbagai budaya yaitu: merusak, mengabaikan, memelihara serta cara memperbaiki lingkungan hidup. Teori ecoculture menerangkan bahwa terhadap keempat model budaya lingkungan itu lebih cenderung terjadi dalam budaya tradisional maupun budaya rasional. Jenis model budaya yang sering merusak dan mengabaikan lingkungan hidup lebih cenderung terjadi dilakukan di dalam budaya rasional. Dalam Teori ini juga di jelaskan bahwa perilaku yang terjadi terhadap manusia mengenai lingkungan hidup akan direspon sesuai dengan model budaya yaitu budaya tradisional dan budaya rasional. ${ }^{22}$

Kesembilan, penelitian yang dilakukan Nur Hudawidiana tentang Pergumulan Islam dengan Budaya Lokal Studi Kasus Masyarakat Samin di Dusun Jepang Bojonegoro, dengan hasil penelitian yaitu proses akulturasi yang terjadi di lingkungan masyarakat Samin konsep tersebut untuk menggambarkan suatu proses panjang yang bertemunya dua atau lebih mengani tata cara nilai antara agama Islam dengan nilai-nilai yang dimiliki oleh masyarakat lokal di mana seorang individu, kelompok dan masyarakat yang bertempat tinggal yang memilki budaya yang kental dan telah dijalankan secara turun temurun. Masyarakat Samin yang awal mulanya menolak ajaran Islam karena bentuk kecintaanya kepada ajaran yang lama yang telah mereka anut dari nenek moyang mereka. Namun, di era sekarang ini

22 Tasdyanto, "Budaya Lingkungan Hidup Komunitas Kota Di Yogyakarta," 2013 Vol. Ii (Oktober). 
sudah ada keterbukaan masyarakat samin untuk sedikit menerima ajaran agama Islam. ${ }^{23}$

Kesepuluh, penelitian yang dilakukan oleh Tarsono tentang Character Building pada Manusia (Analisis Terhadap Budaya Suku Dayak Losarang Indramayu). Penelitian ini mendeskripsikan tentang suatu keunikan yang terdapat pada masyarakat Suku Dayak. Adapun keunikan tersebut meliputi; cara berpakaian suku dayak, cara berkomunikasi suka dayak, cara beribadah serta cara memaknai hidup. Faktor yang mendorong dan faktor yang penarik mereka untuk tetap bertahan dalam kelompok masyarakat adat tersebut yaitu dengan adanya beberapa ritualnya diantaranya yaitu: ritual kungkum, ritual pepe, ngaula ning anak rabi, ritual ruatan putri keraton, pemurnian diri, serta ritual malam Jumat Kliwon. Kesemua ritual dilakukan untuk mengharapkan berkah dari Tuhan. ${ }^{24}$

Kesebelas, penelitian yang dilakukan oleh S. Bayu Wahyono tentang Kejawaan dan Keislaman: Suatu Pertarungan Identitas. Penelitian ini menghasilkan suatu kebangkitan agama Islam yang terjadi dalam berbagai bentuk menjadikan agama Islam mempunyai implikasi yang cukup serius terhadap masalah kehidupan kultural dan keagamaan yang terjadi di masyarakat Jawa. Kebijakan atau aturan negara yang hanya meyakini adanya lima agama yaitu Islam, Protestan, Katholik, Hindu, serta agama Budha. Pemerintahan Orde Baru, secara efektif menyingkirkan dan berusaha menghilang agama pribumi. Para punggawa dakwah dan antropolog yang melakukan penelitian atau pengamatan yang mencari tahu bagaimana pengaruh kebijakan tersebut di berbagai daerah di luar Jawa, dan juga sekaligus mereka sangat berperan sebagai pendakwah yang berdakwah kepada

23 Nurhuda Widiana, "Pergumulan Islam dengan Budaya Lokal Studi Kasus Masyarakat Samin di Dusun Jepang Bojonegoro," 2015 Volume 26, (n.d.): Desember.

24 Tarsono, "Character Building pada Manusia (analisis Terhadap Budaya Suku Dayak Losarang Indramayu)," 2014 Vol. 1, (juni): Hal : 32-48. 
semua masyarakat dan misionaris yang mempercepat konversi atau perubahan dari agama pribumi ke Kristen atau Islami. ${ }^{25}$

Kedua belas, penelitian yang dilakukan oleh Hasbullah tentang Dialektika Islam Dalam Budaya Lokal: Potret Budaya Melayu Riau. Riset ini menunjukkan bahwa Agama Islam yang hadir di tengahtengah budaya Melayu datang dengan membawa konsep-konsep serta nilai-nilai baru yang mampu menggeser serta memperbaiki nilai-nilai yang berbau mistis ke arah pada pemikiran yang bersifat rasional. Agama Islam pun juga mampu memecahkan dan memberikan solusi mengenai permasalahan-permasalahan yang belum terpecahkan dalam keyakinan dan kepercayaan orang Melayu sebelumnya. Begitu luas dan dalamnya pengaruh agama Islam dalam mempengaruhi adat dan kebudayaan Melayu sehingga terdapat banyak masyarakat mengatakan bahwa orang Melayu identik atau mirip dengan agama Islam. Di dalam adat Melayu setelah memeluk agama Islam terdapat pepatah yang berkaitan dengan agama dan budaya. Pepatah tersebut memiliki arti yaitu adat merupakan operasional dari nilai-nilai ajaran agama Islam. Di samping hal itu adat dalam kebudayaan yang dianut Melayu bersumber atau yang memiliki dasar dari agama Islam dan tidak boleh ada pertentangan antara adat dengan Islam, jika terdapat pertentangan atau perselisihan maka hal yang harus diambil yaitu adatlah yang harus mengalah. Hal tersebut sesui dengan pepatah yang diungkapkan dalam pepatah adat yaitu adat bersendi syarak, syarak bersendi kitabullah. Yang memiliki arti yaitu adat tersebut bersal dari syar'a dan syar'a tersebut bersal dari kitab suci atau kitabullah yang dianut dan dijaga oleh masyarakat yang bergama Islam. ${ }^{26}$

Ketiga Belas, penelitian yang dilakukan oleh Mangun Budiyanto, tengan Pergulatan Agama Dan Budaya: Pola Hubungan Islam dan Budaya Lokal di Masyarakat Tutup Ngisor, Lereng Merapi, Magelang Jawa Tengah. Penelitian ini menunjukkan bahwa jika dilihat dari

25 S. Bayu Wahyono, "Kejawaan dan Keislaman: Suatu Pertarungan Identitas," 2001 Volume 5, (Juli): 41-59.

26 Hasbullah, "Dialektika Islam dalam Budaya Lokal: Potret Budaya Melayu Riau," 2014 Vol 11 (Juli - Desember). 
berbagai ritual yang dilaksanakan pada masyarakat Tutup Ngisor terlihat bahwa model atau cara keberagamaan yang berlangsung dan dianut oleh Tutup Ngisor lebih cenderung mendekati tata cara atau model Islam Jawa atau kejawan. Di Tutup ngisor ini mereka menyelaraskan antara budaya dan agama jadi tidak ada pertentangan antara budaya dan agama. Masyarakat Tutup Ngisor juga menyakini bahwa terdapat dua roh yaitu roh jahat dan roh baik, mereka meyakini bahwa dengan diakan setiap ritual mereka selalu memberikan sesajen untuk roh jahat dan roh baik, dengan tujuan diberikan kepada roh baik yaitu agar lingkungan mereka, pertanian mereka dapat terjaga dengan baik oleh roh baik tersebut. Begitupun dengan pemberian sesajen kepada roh jahat mereka meyakini bahwa agar roh jahat tersebut tidak marah dan tidak merusak lingkungan dan pertanian mereka serta tidak menimbulkan malapetaka bagi kehidupan masyarakat Tutup Ngisor. ${ }^{27}$

Berdasarkan berbagai penelitian yang dilakukan dapat di simpulkan bahwa Studi Relasi Antara Pendidikan Islam dan Budaya Mistis dalam Pelestarian Lingkungan yaitu terdapat sisi positif dan sisi negatif. Sisi positifnya yaitu dengan adanya budaya mistis yang ada pada masyarakat menjadikan masyarakat tidak semena-mena terhadap alam, masyarakat yang menganut dan mempercayai adanya mistis ini lebih sopan, lebih berhati-hati ketika melakukan atau berhubungan dengan alam. Sedang sisi negatifnya yaitu masyarakat yang menganut atau mempercayai adanya mistis ini cenderung lebih mengedepankan dan mengagung-agungkan budayanya di banding dengan agama Islam yang dianutnya. Misalnya seperti adanya perayaan ritual terhadap alam mereka memuja dan meminta bantuan kepada roh-roh yang ada di alam tersebut untuk menjaga lingkungan mereka, sedangkan jika menurut agama Islam hal itu cukup dilakukan dengan meminta dan berdoa hanya kepada Allah swt.

27 Mangun Budiyanto, Dkk, "Pergulatan Agama Dan Budaya: Pola Hubungan Islam Dan Budaya Lokal Di Masyarakat Tutup Ngisor, Lereng Merapi, Magelang Jawa Tengah," 2008, No 03, Vol. Xvii, (N.D.): September-Desember. 
Berdasarkan uraian di atas, maka dapat diketahui kekurangan dan kelebihan dari adanya relasi antara pendidikan Islam dan budaya mistis dalam pelestarian lingkungan yaitu:

Kelebihan, pertama masyarakat yang merealisasikan atau percaya akan budaya mistis dalam melestarikan lingkungan yaitu mereka lebih cenderung sopan, dan tidak berlaku semena-mena terhadap alam. Kedua, alam menjadi terjaga dengan baik. Ketiga, tidak terjadi pencemaran lingkungan. Keempat, tidak terjadi pengekplotasian alam secara berlebihan. Kelima, alam lebih terjaga keasrianya. Keenam, menimbulakan silaturahmi yang baik antar masyarakat.

Kekurangan, pertama masyarakat lebih mengagung-agungkan budayanya dibanding agama dan tuhanya, kedua, masyarakat lebih mengelompok sesuai dengan budayanya. Ketiga, adanya penyelarasan atau menyeimbangkan antara agama dan budaya, yang seharusnya agama Islam itu di atas budaya yang dianutnya, namun pada kelompok atau masyarakat yang menganggap dan percaya terhadap mistis tersebut mereka menyelaraskan antara agama dan budaya tersebut.

\section{Kesimpulan}

Dari berbagai penelitian yang dilakukan dapat disimpulkan bahwa studi relasi antara pendidikan Islam dan budaya mistis dalam pelestarian lingkungan yaitu terdapat sisi positif dan sisi negatif. Sisi positifnya yaitu dengan adanya budaya mistis yang ada pada masyarakat menjadikan masyarakat tidak semena-mena terhadap alam, masyarakat yang menganut dan mempercayai adanya mistis ini lebih sopan, lebih berhati-hati ketika melakukan atau berhubungan dengan alam.

Sedang sisi negatifnya yaitu masyarakat yang menganut atau mempercayai adanya mistis ini cenderung lebih mengedepankan dan mengagung-agungkan budayanya dibanding dengan agama Islam yang dianutnya. Misalnya seperti adanya perayaan ritual terhadap alam mereka memuja dan meminta bantuan kepada roh-roh yang ada di alam tersebut untuk menjaga lingkungan mereka, sedangkan jika 
menurut agama Islam hal itu cukup dilakukan dengan meminta dan berdoa hanya kepada Allah swt.[]

\section{Daftar Pustaka}

Alamsyah, Ali. "Proses Enkulturasi dalam Budaya Entas-entas, Praswala Gara, Dan Pujan Kapat (Sistem Sosial Lokal: Antar Etnis Kabupaten Probolinggo)." Jurnal komunikatio 1, no. 1 (2017).

Budiyanto, dkk, mangun. "Pergulatan Agama Dan Budaya: Pola Hubungan Islam Dan Budaya Lokal Di Masyarakat Tutup Ngisor, Lereng Merapi, Magelang Jawa Tengah." 2008, no 03, Vol. XVII, (n.d.): September-Desember.

Departemen Agama RI. Al-Quran Tajwid dan terjemah. Bandung: CV. Penerbit Diponegoro, 2010.

Hasanah, Muhibbatul. "Mitos Ikan Lele: Studi Deskriptif Masyarakat Desa Medang, Kecamatan Glagah, Kabupaten Lamongan." Juli-Desember II (2013): 157-156.

Hasbullah. “Dialektika Islam Dalam Budaya Lokal: Potret Budaya Melayu Riau." 2014 Vol 11 (Juli - Desember).

Hidayat, Ara. "Pendidikan Islam dan Lingkungan Hidup." Jurnal Pendidikan Islam 4, no. 2 (1 Desember 2015): 373. https://doi.org/10.14421/jpi.2015.42.373-389.

Johan Purnama. Agama dan Budaya Lokal di Indonesia. Jakarta Selatan: Agama dan Budaya Lokal di Indonesia, 2015.

Karomi, Kholid. "Tuhan dalam Mistik Islam Kejawen (Kajian atas Pemikiran Raden Ngabehi Ranggawarsita)." Kalimah 11, no. 2 (2013): 287-304.

La Fua, Jumarddin. "Aktualisasi Pendidikan Islam dalam Pengelolaan Lingkungan Hidup menuju Kesalehan Ekologis." Al-Ta'dib 7, no. 1 (2014): 19-36.

- - - "Aktualisasi Pendidikan Islam dalam Pengelolaan Lingkungan Hidup menuju Kesalehan Ekologis." Al-Ta'dib 7, no. 1 (2014): 1936. 
Mahsun, Ali. "PEndidikan Islam Dalam Arus Globalisasi Sebuah Kajian Deskriptif Analitis." 2013 Vol. 8, (Desember).

Miharji, Deni. "Wujud Kebudayaan Masyarakat Adat Cikondang Dalam Melestarikan Lingkungan." September 1 (2016): 51-61.

Muspiroh, Novianti. "Peran Pendidikan Islam Dalam Pelestarian Lingkungan," n.d.

Muzakki, Ahmad. "Islam via a vis Orang Rimba: Studi Konsep Pendidikan Lingkungan Hidup Orang Rimba dalam Seloko Pesemian", Akademika, Vol. 19, No. 02, Juli - Desember 2014.

Napsiah, Napsiah. "Kontekstualisasi Kepercayaan Warga Lokal dalam Menjaga Lingkungan Gunung Merapi." Kontekstualita 31, no. 1 (2017): 37-54.

Tarsono. "Character Building Pada Manusia (Analisis Terhadap Budaya Suku Dayak Losarang Indramayu)." 2014 Vol. 1, (Juni): Hal : 3248.

Tasdyanto. "Budaya Lingkungan Hidup Komunitas Kota Di Yogyakarta." 2013 Vol. II (oktober).

Wahyono, S. Bayu. "Kejawaan Dan Keislaman: Suatu Pertarungan Identitas." 2001 Volume 5, (Juli): 41-59.

Wibowo, Afif Andi. "Persepsi Masyarakat Terhadap Mitos Air Tiga Rasa Di Lingkungan Makam Sunan Muria Kabupaten Kudus." Juli, 2011.

Widagdo, Haidi Hajar. "Relasi Alam Dan Agama (Sebuah Upaya Penyelarasan antara Budaya Mistis dengan Pelestarian Lingkungan)." ESENSIA: Jurnal Ilmu-IImu Ushuluddin 13, no. 2 (2012): 263-276.

Widiana, Nurhuda. "Pergumulan Islam Dengan Budaya Lokal Studi Kasus Masyarakat Samin di Dusun Jepang Bojonegoro." 2015 Volume 26, (n.d.): Desember.

Yasin. "Implementasi Pendidikan Agama Islam Berbasis Konservasi Lingkungan Hidup Dalam Membentuk Karakter Siswa." 2017, Maret.

Yusof, Abdullah. "Relasi Islam Dan Budaya Lokal: Studi Tentang Tradisi Nyadran Di Desa Sumogawe Kecamatan Getasan Kabupaten Semarang." IAIN Tulungagung Research Collections 4, no. 1 (n.d.). 